\title{
POTRZEBY, MOŻLIWOŚCI I KONTEKSTY WPROWADZENIA DO NAUCZANIA JEZZYKA POLSKIEGO JAKO OBCEGO TREŚCI ZWIĄZANYCH Z PRAWAMI CZLOWIEKA
}

Słowa kluczowe: nauczanie języka polskiego jako obcego, prawa i wolności człowieka, dia$\log$ międzykulturowy

Streszczenie. Artykuł omawia wprowadzenie tematyki związanej z prawami człowieka do cyklu kształcenia językowego cudzoziemców na zajęciach języka polskiego jako obcego. Prezentowane refleksje bazują na wynikach projektów realizowanych na Uniwersytecie Zielonogórskim w latach 2017-2020. Odbiorcami tych działań są głównie dorośli cudzoziemcy, którzy z dużym entuzjazmem i obopólną korzyścią przyjmują poszerzenie treści nauczania o zagadnienia z praw człowieka. Rozmowa na te tematy zawsze wiąże się z ujawnianiem przyjętej przez słuchaczy (świadomie lub nie) ideologii, filozofii społecznej. Aktywizuje słuchaczy i pozwala płynnie przejść od nauczania słownictwa i struktur gramatycznych do względnie naturalnej komunikacji. Wydaje się korzystne poszerzenie słownictwa tematycznego i ról komunikacyjnych o te formy, które uczyłyby zachowań komunikacyjnych potrzebnych cudzoziemcom w rozmaitych sytuacjach, w których może dochodzić do łamania ich praw. Wprowadzenie elementów wiedzy z zakresu praw człowieka do nauczania języka polskiego może stwarzać szeroką i funkcjonalną podstawę do dialogu międzykulturowego, który ma duży wpływ na motywację do nauki, kształtuje postawę aktywności i otwartości, a także wzbogaca interakcję.

Wiedza o prawach człowieka dla cudzoziemców uczących się języka polskiego ze względu na potrzeby podstawowe, w tym zapewnienia sobie i rodzinie bezpiecznego miejsca pobytu, godnych warunków pracy i rozwoju, jest szczególnie istotna. Zainteresowanie obcą kulturą pozostaje przecież w ścisłym związku

*I.Palucka-Czerniak@ifp.uz.zgora.pl, Uniwersytet Zielonogórski, Instytut Filologii Polskiej, al. Wojska Polskiego 67, 65-001 Zielona Góra. 
z poszanowaniem prawa człowieka do poczucia i wyrażania własnej tożsamości narodowej, kulturowej, językowej (por. Steciąg 2014). Wprowadzenie tej tematyki do zajęć z języka polskiego jako obcego w formie odrębnych warsztatów wzbogaca ofertę dydaktyczną i stwarza dodatkowe możliwości współdziałania w grupie. Możliwe jest również włączenie elementów wiedzy o prawach człowieka w standardowy kurs języka polskiego dla cudzoziemców, zarówno na poziomie początkującym, jak i na bardziej zaawansowanym.

Poruszane zagadnienie wiąże się bezpośrednio z projektami realizowanymi na Uniwersytecie Zielonogórskim, adresowanymi do cudzoziemców przebywających w Polsce, w czasie których oprócz nauczania języka polskiego i integracji realizowane były zajęcia z praw człowieka. Dotyczy to czterech inicjatyw, finansowanych ze źródeł zewnętrznych, adresowanych do osób dorosłych, które miały miejsce w latach 2017, 2018 i 2019-2021. Wszystkie one powstały we współpracy z Zielonogórskim Towarzystwem Edukacyjnym „Civilitas”, od lat zajmującym się przeciwdziałaniem wykluczeniu społecznemu oraz rozpowszechnianiem wiedzy na temat praw człowieka. Warsztaty z praw człowieka w ramach tych projektów zostały zrealizowane dotąd dla 259 osób, w tym 184 w ramach ostatniego projektu unijnego.

Pierwsze trzy projekty: Język oknem na świat, Z komunikacja ku integracji oraz Dwa kroki do integracji: kultura i język z lat 2017 i 2018 były odpowiedzią na rosnące potrzeby cudzoziemskiej społeczności lokalnej o poziomie językowym bliskim zaawansowanego. W cykl rozmaitych zajęć dydaktycznych i integracyjnych były wplatane treści związane z prawami człowieka, odbywały się też krótkie szkolenia i pogadanki na ten temat. Okazało się szybko, że podstawową motywacją cudzoziemców do uczestnictwa w projektach nie było pogłębianie wiedzy o prawach człowieka, ale nauka języka polskiego. Dopiero po wzięciu udziału w zajęciach o tematyce związanej z prawami człowieka słuchacze stwierdzali, że treści te są niezwykle interesujące oraz chętnie kontynuowaliby naukę w czasie tego typu spotkań. Dawali temu wyraz w rozmowach oraz pisemnych ewaluacjach przeprowadzanych na koniec projektów. Potrzeba pogłębienia wiedzy o prawach człowieka nie jest przez cudzoziemców zgłaszana zanim nie uświadomią sobie znaczenia tych treści dla zrozumienia świata, który ich otacza. Wyraźnie zaś było widoczne rozbudzenie ciekawości i aktywizacja społeczna po tego typu zajęciach.

$\mathrm{Na}$ bazie tych pierwszych doświadczeń został przygotowany projekt unijny, który rozpoczął się w 2019 roku. Jest on znacznie bardziej rozbudowany i rozciągnięty w czasie. Zaproponowane za pośrednictwem Narodowego Centrum Badań i Rozwoju zadanie pt. Stucham, rozumiem, działam. Poszerzanie kompetencji językowych cudzoziemców w celu zapobiegania alienacji społeczno-zawodowej ${ }^{1}$ jest współfinansowane z Funduszy Europejskich. Jego podstawowym założeniem

${ }^{1}$ Projekt w ramach Programu Operacyjnego Wiedza Edukacja Rozwój 2014-2020, Oś Priorytetowa III Szkolnictwo wyższe dla gospodarki i rozwoju, Działanie 3.1 Kompetencje w szkolnictwie wyższym, beneficjent: Uniwersytet Zielonogórski, partner: Zielonogórskie Towarzystwo Edukacyjne „Civilitas”. 
stało się przeszkolenie 165 cudzoziemców w zakresie języka polskiego na różnych poziomach kompetencji językowej, poszerzenie ich wiedzy prawnej oraz ich aktywizacja społeczna². Nieprzypadkowo sześćdziesięciogodzinnemu kursowi języka polskiego towarzyszą ośmiogodzinne warsztaty z praw człowieka. $\mathrm{Na}$ tych zajęciach, prowadzonych przez edukatora ZTE „Civilitas”, słuchacze poznają prawa i wolności człowieka, w tym prawa dziecka, rozmawiają na temat praw i obowiązków cudzoziemców w Polsce, wymieniają się doświadczeniami oraz omawiają sposób zachowania w sytuacji zagrożenia. Ogólnym efektem projektu jest podwyższenie kompetencji zawodowych i komunikacyjnych cudzoziemców, wzrost wiedzy o prawach człowieka, a także pośrednio - wypracowanie materiałów dydaktycznych, z których będzie można korzystać po zakończeniu projektu. Działaniu przyświeca ogólny cel aktywizacji cudzoziemców i rozbudzenia zainteresowania nauką języka polskiego, stworzenia bezpiecznego miejsca, w którym można wyrazić siebie i mówić o swoim doświadczeniu życiowym. Pojedynczy udział w projekcie trwa jednak za krótko, by cudzoziemiec opanował dany poziom języka czy przyswoił większy zakres wiedzy o prawach człowieka. Podejście do nauczania zatem w czasie tych zajęć ma charakter odmienny od standardowego, jest mocno spersonalizowane, zależy od zidentyfikowanych potrzeb słuchaczy i indywidualnej koncepcji nauczyciela.

Same warsztaty z praw człowieka odbywają się w pięciu grupach rocznie, dla słuchaczy zróżnicowanych wiekiem, krajem pochodzenia, zaawansowaniem w języku polskim, zwykle pod koniec kursu języka polskiego dla cudzoziemców. Działanie w czasie tych zajęć nie tyle koncentruje się na nauce języka polskiego, ile na przekazywaniu wiedzy i wymianie informacji oraz poglądów, związanych z prawami człowieka Choć specjaliści z praw człowieka nie są glottodydaktykami, współpracują z nauczycielami prowadzącymi kursy w celu wypracowania optymalnej formy zajęć. Szczególnym wyzwaniem staje się tu przekazanie specjalistycznej wiedzy, niekiedy wymagającej znajomości treści z zakresu prawa, osobom o różnym wykształceniu i rozmaitych kompetencjach komunikatywnych. Efektem działania nie ma być przygotowanie cudzoziemców do studiowania prawa ani czytania tekstów w języku naukowym czy prawniczym (zob. Grzelak 2010). Warsztaty mają pobudzać do refleksji, inspirować do dyskusji oraz wskazywać podobieństwa i różnice w podejściu do rozmaitych, aktualnych problemów związanych z przestrzeganiem praw człowieka.

Nauka języka polskiego, w sposób konieczny obecna na tych warsztatach ${ }^{3}$, jest ściśle związana z konkretnymi zadaniami stawianymi przed słuchaczami. Aktywizują oni już posiadaną wiedzę na temat praw człowieka, poszerzają ją w dyskusji, samodzielnie lub w grupie rozwiązują stawiane przed nimi problemy,

\footnotetext{
${ }^{2}$ Ostatecznie do projektu przystąpiło 206 cudzoziemców, a 173 ukończyło szkolenie.

${ }^{3}$ Warsztaty, prowadzone w języku polskim, wprowadzają bowiem nową leksykę i frazeologię oraz pozwalają na trenowanie dyskusji oraz uczą strategii negocjacyjnych w komunikacji.
} 
poznają odmienne poglądy, uświadamiają sobie różnice kulturowe. Język służący komunikacji jest pośrednikiem do realizacji celu, zatem jego uczenie się zbliża się wyraźnie do koncepcji CLIL (Content and Language Integrated Learning) (por. Rzeszutko-Iwan 2016). Na wspomnianych warsztatach, niezależnie od poziomu grupy, wytwarza się przestrzeń do dialogu międzykulturowego, a także kształtowana jest postawa otwartości i tolerancji. Korzyści płynące z osiągnięcia tego poziomu komunikacji wewnątrz grupy są nieocenione. Jak pisze Tadeusz Paleczny,

„Dialog międzykulturowy zachodzi, po pierwsze, w pewnej wspólnej dla wszystkich kultur składowych przestrzeni. Przestrzeń dialogu z zasady prowadzi do uniwersalizacji postaw, zachowań i tożsamości uczestników. Jest to z jednej strony suma kultur zbiorowości składowych, jak ich iloczyn. $Z$ jednej strony przestrzeń dialogu wyznacza granice kulturowe, definiuje i podtrzymuje kryteria odrębności, z drugiej tworzy kontekst transkulturowej, transgranicznej sfery wartości i znaczeń, który jest wspólny dla wszystkich uczestników dialogu" (Paleczny 2016, s. 80).

W praktyce po zajęciach z praw człowieka następuje zwykle duży progres w integracji społecznej osób w nich uczestniczących, zmienia się nastawienie do nauki języka polskiego, wzrasta poziom aktywności na zajęciach z języka polskiego i wzajemne zrozumienie. Słabsze osoby otrzymują większe wsparcie grupy, a tematyka rozmów się pogłębia. Rozwiązują się niekiedy swoiste problemy i wyzwania, związane z odmiennością kulturową, ważne zarówno dla nauczyciela, jak i dla słuchaczy. Niezależnie od poziomu grupy przekaz wiedzy i doświadczenia splata się z nauką wyrażania tych treści w języku polskim, a poznawanie nowej leksyki i struktur gramatycznych jest traktowane utylitarnie, jako narzędzie do realizacji większego celu. Jednakże przygotowanie tych warsztatów wymaga zindywidualizowanego podejścia do poszczególnych grup.

Podstawowym uwarunkowaniem tych zajęć jest specyfika odbiorcy. W projektach biorą udział cudzoziemcy, osoby dorosłe, pochodzące w dużej mierze z krajów słowiańskojęzycznych, w tym w około 70\% z Ukrainy, ale i z Białorusi oraz Rosji. Wśród niesłowiańskojęzycznych słuchaczy znaleźli się reprezentanci różnych nacji, posługujący się m.in. językami: arabskim, hindi, japońskim, filipińskim, angielskim, suahili. W projekcie Stucham, rozumiem, działam... są oni dzieleni na grupy ze względu na deklarowany i weryfikowany poziom języka, w zespoły względnie odpowiadające standardowemu określaniu poziomów zaawansowania w języku. Poza tym warsztaty z praw człowieka odbywają się pod koniec kursu, zatem najważniejsza wydaje się informacja od nauczyciela języka polskiego, który jest w stanie wskazać możliwości i potrzeby słuchaczy.

O ile na poziomie zaawansowanym nauczyciel raczej dokonuje wyboru i ma wiele możliwości realizowania szerokiego spektrum tematów związanych z prawami człowieka, a także korzysta $\mathrm{z}$ tekstów autentycznych, wywiadów, filmów, piosenek, tekstów prawnych i prawniczych, o tyle zajęcia na poziomie podstawo- 
wym A1 i A2 wymagają szczególnego przygotowania i refleksji nad możliwym zakresem tematycznym i metodą. Okazuje się jednak, że w przypadku osób dorosłych, przebywających w obcym kraju, szczególnie dotkliwe jest zablokowanie możliwości wyrażania własnych uczuć, potrzeb i poglądów, a w ich miejsce wprowadzenie komunikacji minimalistycznej. Dlatego mimo że tematyka zajęć może się wydawać zbyt trudna, zwłaszcza na poziomie A1, korzystne jest jej dostosowanie do możliwości słuchaczy, m.in. poprzez uproszczenie treści. W czasie warsztatów większy nacisk kładzie się na budowanie w słuchaczach poczucia własnej wartości, godności, m.in. poprzez wypowiedzi na tematy dotyczące ich ojczyzn, języków i własnych doświadczeń. W miarę potrzeb, głównie na początkującym poziomie, nauczyciel pozwala na swobodną wymianę informacji we wszystkich znanych przez słuchaczy językach.

Osoby te wielokrotnie podkreślają, że w praktyce codziennej korzystają z wielu ułatwień wynikających z przekształceń technologicznych środków przekazu, z form działania, w których kontakt słowny jest ograniczony. Żyją w środowisku, które nie wymusza poznania języka polskiego, choć zdają sobie sprawę z tego, że nauczenie się języka to podstawowe działanie umożliwiające stabilizację pobytu w Polsce i zwykle konieczne dla polepszenia standardu życia. Przy dość powszechnej znajomości języka angielskiego radzą sobie na poziomie podstawowej komunikacji, wystarczającej do zaspokojenia fundamentalnych potrzeb. Zdarzają się słuchacze, którzy deklarują, że w Polsce żyją i pracują od kilku lat, a mimo to naukę języka polskiego rozpoczynają na poziomie podstawowym lub podstawowym rozszerzonym. Dość szybko sygnalizują wówczas nie tylko potrzebę nauczenia się komunikowania w sytuacjach codziennego życia, ale przede wszystkim wyrażenia siebie, swoich fascynacji, poglądów i przeżyć. Stąd szczególny potencjał kryje się w tematyce praw człowieka, włączanej do zajęć z języka polskiego jako obcego na wszystkich poziomach jego nauczania. Wydaje się, że potrzeba ta wynika z dwóch czynników: wieku słuchaczy (dominują osoby w wieku od 25 do 40 lat) oraz długości ich pobytu w Polsce (zwykle od pół roku do 2 - 3 lat, ale zdarzają się również osoby przebywające tu od lat 10). Inne zmienne: poziom wykształcenia oraz profil zawodowy, stan majątkowy i sytuacja społeczna, są różne, co dokumentują deklaracje zgłoszeniowe słuchaczy oraz co ujawnia się $\mathrm{w}$ ich wypowiedziach $\mathrm{w}$ trakcie zajęć.

Swoistą potrzebą jest zapewnienie odpowiednio wyszkolonej w tym zakresie kadry nauczycielskiej. Dlatego projekty wspiera Zielonogórskie Towarzystwo Edukacyjne „Civilitas”, które na rzecz upowszechniania wiedzy o prawach człowieka działa już od lat 90 . XX wieku. Oficjalny początek tej instytucji pożytku publicznego datuje się na marzec 1997 roku. Wtedy to z inicjatywy zielonogórskiej grupy absolwentów Helsińskiej Szkoły Praw Człowieka w Warszawie, realizującej rozmaite projekty edukacyjne o prawach człowieka, zostało zarejestrowane stowarzyszenie. Od ponad 20 lat przez tę instytucję są prowadzone 
szkolenia, warsztaty, wymiany, festiwale i konkursy, które mają na celu m.in. upowszechnianie wiedzy o prawach człowieka, wymianę doświadczeń oraz praktyczną działalność na rzecz przeciwdziałania wykluczeniu społecznemu. Członkowie stowarzyszenia nie tylko przeszli odpowiednie szkolenia w tym zakresie, ale stale poszerzają warsztat metodyczny i współpracują z Ośrodkiem Doskonalenia Nauczycieli. Oni to właśnie zaproponowali w 2017 roku podjęcie inicjatyw mających na celu wspieranie cudzoziemców w nauce języka polskiego i integracji społecznej. Działania te skoncentrowane były na organizowaniu szkoleń oraz pozyskiwaniu środków na bezpłatne nauczanie cudzoziemców. Dzięki tej współpracy kursy języka polskiego jako obcego zostały poszerzone o szkolenia z praw człowieka, realizowane przez wyspecjalizowaną kadrę.

Ideałem byłoby, oczywiście, żeby nauczyciel języka polskiego jako obcego, reprezentujący instytucję państwową, również posiadał pogłębioną wiedzę o prawach człowieka. Nauczanie języka polskiego jako obcego, wynikające z systemowego zaspokajania potrzeb społecznych, wiąże się przecież z rozumieniem idei godności, równości, wolności, bezpieczeństwa, prawa do ochrony prawnej i społecznej, edukacji. Tradycja myśli filozoficznej oraz dzieje kultury europejskiej sprawiają, że idee te są w szerokich kręgach społecznych rozumiane i w dużej mierze akceptowane. Jednak wprowadzanie do edukacji informacji o prawach człowieka jest nadal dla systemu polskiej oświaty wyzwaniem (por. Domagała, Florczak 2018).

Mówi się co prawda o pewnym globalnym zasobie wiedzy, ponadregionalnym swoistym standardzie. Nie bez znaczenia jest fakt, że fundament współczesnego rozumienia praw człowieka tworzą dwa dokumenty: Karta Narodów Zjednoczonych z 1945 roku oraz Powszechna Deklaracja Praw Człowieka, uchwalona przez Zgromadzenie Ogólne ONZ w 1948 roku. Od tego czasu wiele państw przyjęło te wytyczne oraz wprowadzało je we własne systemy prawne, a liczba i znaczenie organizacji międzynarodowych, stojących na straży tego prawa, stale rosła (Rzepliński 1992). W przestrzeni międzynarodowej wypracowywane są wspólne standardy funkcjonowania społeczeństw, co przekłada się na regulację rozmaitych sektorów życia społecznego. Między innymi następuje upowszechnianie wiedzy o prawach człowieka i modelowanie postaw społecznych przez system edukacji. Płynie stąd glottodydaktyczna korzyść - cudzoziemscy słuchacze wspomnianych wyżej warsztatów zwykle posiadają wiedzę o prawach człowieka, choć o różnym stopniu zaawansowania i utrwalenia. Na prowadzonych zajęciach niezwykle zaskakujące bywa podawanie podstaw teoretycznych przez słuchaczy z Ukrainy, Indii czy Algierii, niekiedy w ich rodzimym języku lub języku pośredniku. Oczywiście, największe zainteresowanie prawami człowieka wyrażają członkowie społeczeństw, które są w fazie silnych przekształceń, a bliska ich historia obfituje w doświadczenia związane $\mathrm{z}$ łamaniem praw człowieka (por. Piechowiak 1999). 
Tematyka związana z prawami człowieka na zajęciach z języka polskiego jako obcego w kształceniu osób dorosłych spełnia swoiste kryterium aktualności poruszanych treści, a więc aktywizuje dużą grupę uczestników do wyrażania własnych poglądów i przedstawiania własnych doświadczeń. Buduje tym samym płaszczyznę porozumienia, choć zostawia też duże pole do negocjacji znaczeń i hierarchii wartości. Powszechność tych treści w wielu systemach edukacyjnych korzystnie wpływa na integrowanie wiedzy przyswojonej wcześniej, w języku znanym uczestnikom, z treściami wyrażonymi w języku nabywanym. Konieczność upowszechniania tej wiedzy wynika również ze specyfiki funkcjonowania prawa polskiego, czyli z wyjaśniania znaczenia rozwiązań prawnych, wynikających np. z prawa do ochrony życia, prawa do informacji. Na przykład zaskakujące dla większości słowiańskich słuchaczy kursów języka polskiego dla cudzoziemców i warsztatów z praw człowieka na Uniwersytecie Zielonogórskim było stwierdzenie, że dziecko do 8 roku życia w Polsce nie może pozostawać bez opieki dorosłego lub że w procedurze składania dokumentów na pobyt w Polsce cudzoziemcowi przysługują określone prawa. Charakterystyczne okazywało się przejęcie inicjatywy w dyskusji przez uczestników warsztatów, dość swobodne zmienianie pól tematycznych oraz pozostawanie w kręgu zagadnień kulturalno-historycznych (por. Zarzycka 2019). Zakorzenienie w pojęciu praw człowieka takich zagadnień jak np. ochrona środowiska, dostęp do informacji, zwyczaje religijne, symbole narodowe nie jest trudne, a nadaje im głębszy wymiar. Jednocześnie trzeba zaznaczyć, że tematy dotykające wartości związanych z prawami człowieka (godności i wolności, równości, tolerancji i sprawiedliwości), ich hierarchii oraz prawnych rozwiązań służących ich ochronie budzą niekiedy skrajne emocje, wynikające z osobistego doświadczenia słuchaczy.

Można realizować warsztaty z praw człowieka jako osobne zajęcia, można też wprowadzać te treści w cykl dydaktyczny języka polskiego jako obcego. Nie zawsze bowiem możliwe, a nawet korzystne jest wyodrębnienie treści związanych z prawami człowieka. Warto zatem przyjrzeć się, które treści zawarte w programach nauczania języka polskiego jako obcego (Programy nauczania... 2011) wiążą się z zagadnieniami pozostającymi w kręgu tematycznym praw człowieka. Programy nauczania języka polskiego jako obcego już od poziomu A1 zakładają stworzenie słuchaczom możliwości poznawania samego siebie w kontakcie z osobami pochodzącymi z różnych krajów, kultur i języków. W procesie kształcenia ma być rozwijana kompetencja interkulturowa, pozwalająca na dostrzeganie podobieństw i różnic kulturowych. To dążenie wpisuje się w ogólnie rozumianą wolność wyrażania poglądów, prawo do niedyskryminacji społecznej ze względu na przekonania, wyznanie czy wygląd. Na poziomie A1 w pierwszej chwili najtrudniej wskazać realizację tematyki związanej z prawami człowieka. Jednakże szybko okazuje się, że w kategorii prawa do własnej tożsamości mieści się umiejętność przedstawiania się, określania pochodzenia, języka, przynależności 
wyznaniowej. Tożsamość jest pojęciem złożonym, ale o fundamentalnym znaczeniu dla jednostki ludzkiej. Jerzy Nikitorowicz definiuje ją jako:

twórczy wysiłek podmiotu, łagodzący napięcia i sprzeczności pomiędzy stałymi, odziedziczonymi elementami, wynikającymi z zakotwiczenia społecznego w rodzinie i społeczności lokalnej, identyfikacji z osobami i grupami, symbolami i wartościami rdzennymi a elementami zmiennymi, nabywanymi, wynikającymi z uczestnictwa w kulturze i strukturach społecznych oraz z przyswojonych norm, wartości i zachowań.

(Nikitorowicz 2004, s. 46)

W programach nauczania języka polskiego jako obcego, w zalecanych treściach dla poziomu A1: funkcjach informacyjnych i mediacyjnych, mieszczą się treści związane z pytaniem o informację, a jednym z głównych praw człowieka jest prawo do dostępu do informacji. W funkcjach działania zaś mieści się prośba, zgoda czy odmowa spełnienia prośby bądź żądania. Samo zaś wyrażanie potrzeb, upodobań i życzeń pozwala określać granice tolerancji. W proponowanych na tym poziomie rolach komunikacyjnych znajduje się relacja lekarz - pacjent. Wiąże się ona z prawem każdego człowieka do ochrony zdrowia, m.in. poprzez dostęp do opieki medycznej i podmiotowe traktowanie każdego pacjenta. Na kolejnych poziomach nauczania proponowane treści socjokulturowe, realioznawcze i historyczne daje się łatwo połączyć z osobistymi oraz politycznymi prawami i wolnościami człowieka, z elementami wiedzy o prawach gospodarczych, socjalnych i kulturalnych. Większość typowych tematów do dyskusji łączy się w warstwie głębokiej z tematyką praw człowieka. Na przykład standardowy temat o zwyczajach świątecznych daje asumpt do refleksji nad prawem do wolności myśli, sumienia i wyznania. Omawianie sposobów spędzania wolnego czasu wiąże się często z prawem do swobodnego poruszania się, przemieszczania się ( $\mathrm{w}$ tym do podróży, turystyki). Tematy związane z edukacją łączą się bezpośrednio z prawem do edukacji. W kształtowaniu umiejętności tworzenia wypowiedzi argumentacyjnej na zadany temat możliwość pogłębienia refleksji w oparciu o tematykę praw człowieka pozwala na pełniejsze wyrażenie własnych poglądów.

Jest też wiele możliwości łączenia treści gramatycznych i wprowadzania nowej leksyki z zagadnieniami z zakresu praw człowieka. Przykładem niech będzie tylko jedno zagadnienie: prawo do własnej tożsamości, identyfikacji. Jednym z pierwszych tematów powiązanych z nauczaniem języka polskiego i prawami człowieka jest przedstawianie się i zapoznawanie się z innymi. Temat, w którym cudzoziemiec uczy się poprawnie przedstawiać, w podręcznikach do nauczania języka polskiego jako obcego jest umiejscawiany zwykle na samym początku edukacji, a uwaga słuchaczy skupia się na podstawowych formach (auto)prezentacji. W każdej prowadzonej w ramach projektów grupie, niezależnie od poziomu, zapoznawanie się ze słuchaczami, (auto)prezentacja stanowiła pierwszy element spotkania. Przy tej okazji w każdej grupie pojawiały się liczne problemy, wynikające $\mathrm{z}$ wymawiania obco brzmiących nazw, mylenia imienia z nazwi- 
skiem, rozmaitych strategii identyfikowania rozmówców. Te ostatenie wyrażały się $\mathrm{w}$ nadawaniu słuchaczom przez otoczenie czy przybieraniu przez nich samych nowego imienia czy przydomka, zwykle bliskiego kulturze, z którą chce być identyfikowany. Ta sytuacja bezpośrednio wiąże się z prawem do zachowania własnego imienia i nazwiska, z prawem do własnej tożsamości. Poprawna identyfikacja imienia i nazwiska jest ważna nie tylko z prostych przyczyn administracyjnych, ale też ze względu na poczucie własnej tożsamości. Równie istotne wydaje się wyjaśnianie przyczyn pomyłek, niekiedy silnie związanych z różnicami kulturowymi.

Kontynuując ten wątek na późniejszych zajęciach lub w grupach bardziej zaawansowanych, nauczyciel może wprowadzić pojęcie odmiany rzeczownika przez przypadki na podstawie odmiany imion (rzadziej nazwisk) słuchaczy. Ten element wzbudza zawsze dużo entuzjazmu w grupie, zwłaszcza gdy tylko część nazw własnych daje się dopasować do systemu polskiej odmiany. Korzyści są dwie: świadomość językowa zwiększa się, a przynajmniej poszerzeniu ulega zasób wiedzy gramatycznej, ponieważ cudzoziemiec dowiaduje się, że polskie rzeczowniki odmieniają się przez przypadki lub przypomina sobie deklinację rzeczownika. Ponadto wprowadzana jest wiedza z zakresu komunikacji praktycznej, zakorzeniona w rozumieniu kultury, gdyż słuchacz ma okazję zapoznać się ze wzorem odmiany własnego imienia lub imienia i nazwiska oraz typowymi sytuacjami, w których może się spotkać z tymi formami. Ten drugi cel wydaje się ważniejszy dla społecznego funkcjonowania uczestników. Oczywiscie, zakres gramatycznego zagadnienia deklinacji rzeczownika za każdym razem dostosowywany był do potrzeb i możliwości słuchaczy. Przy okazji okazywało się, że wołacz, forma zwykle nauczana na późniejszych lekcjach, jest bardzo potrzebny właśnie na początku komunikacji. Na zajęciach projektowych zdarzało się również przy okazji (auto)prezentacji rozmawianie o konwencji i semantyce oraz stereotypach. Wiązało się to z sytuacjami, gdy obce imię męskie było zakończone końcówką -a i w polskim systemie gramatycznym odmieniało się zgodnie z paradygmatem nazw rodzaju żeńskiego. Identyfikacja wzorca odmiany rodziła problemy natury kulturowej. Poprawna identyfikacja płci okazała się dla słuchaczy niezwykle ważna, ponieważ poznanie wspomnianego faktu stawało się powodem do przekształcania brzmienia nazwy własnej. W bardziej zaawansowanych grupach przy okazji tematu przedstawiania się i zwracania się do innych wyjaśniane było zjawisko używania zdrobnień, spieszczeń i zgrubień nazw własnych (formy i funkcji).

Doświadczenie projektowe na Uniwersytecie Zielonogórskim prowadzi do wniosku, iż dorośli słuchacze z dużym entuzjazmem i obopólną korzyścią przyjmują poszerzenie treści nauczania o zagadnienia z praw człowieka. Chętnie konfrontują własne poglądy i doświadczenia z przeżyciami kolegów w grupie oraz dyskutują na temat bardzo stereotypowych przedstawień nacji i ról społecznych, w tym również obecnych w materiałach dydaktycznych. Rozmowa na tematy 
związane z prawami człowieka zawsze wiąże się z ujawnianiem przyjętej przez słuchaczy (świadomie lub nie) ideologii, filozofii społecznej. Po pierwsze więc wydaje się korzystne poszerzenie słownictwa tematycznego i ról komunikacyjnych o te formy, które uczyłyby zachowań komunikacyjnych potrzebnych cudzoziemcom w rozmaitych sytuacjach, w których może dochodzić do łamania ich praw. Po drugie, wprowadzenie elementów wiedzy z zakresu praw człowieka do nauczania języka polskiego może stwarzać szeroką i funkcjonalną podstawę do dialogu międzykulturowego, który ma duży wpływ na motywację do nauki, kształtuje postawy aktywności i otwartości, a także wzbogaca interakcję.

\section{BIBLIOGRAFIA}

Ciechanowski J., Czyż E., Szewczyk E. (red.), 2002, Prawo do nauki. Raport z monitoringu, Warszawa.

Domagała A., Florczak A., 2018, Prawa człowieka. Materiały edukacyjne, Wrocław, https:/eul.ceo. org.pl/sites/eul.ceo.org.pl/files/prawa_czlowieka.pdf (dostęp: 15.05.2020).

Gawlicz K., Rudnicki P., Starnawski M. (red.), 2015, Dyskryminacja w szkole-obecność nieusprawiedliwiona. O budowaniu edukacji antydyskryminacyjnej $w$ systemie edukacji formalnej $w$ Polsce. Raport z badań, Warszawa.

Grzelak J., 2010, Polski język prawa - w perspektywie glottodydaktycznej, Poznań.

Janowska I., Lipińska E., Rabiej A., Seretny A., Turek P. (red.), 2011, Programy nauczania języka polskiego jako obcego. Poziomy A1-C2, Kraków.

Nikitorowicz J., 2004, Kształtowanie tożsamości kulturowej współczesnego człowieka, w: Edukacja międzykulturowa. Poradnik dla nauczyciela, A. Klimowicz (red.), Warszawa, s. 45-53.

Paleczny T., 2016, Ksztaltowanie kompetencji komunikacyjnej $w$ relacjach międzykulturowych, w: Biblioteka „LingVariów” Glottodydaktyka t. 13: Język, literatura i kultura polska w świecie, W. Miodunka, A. Seretny (red.), Księgarnia Akademicka, Kraków, s. 73-86.

Piechowiak M., 1999, Filozofia praw człowieka, Lublin.

Rzepliński A. (red.), 1992, Prawa i wolności człowieka, Warszawa.

Rzeszutko-Iwan M., 2016, Przekaz wiedzy, czyli nauczanie specjalistycznej odmiany języka - w kontekście pedagogiki CLIL, „Acta Uniwersitatis Lodziensis. Kształcenie Polonistyczne Cudzoziemców” 23, s. 97-113.

Steciąg M., 2014, Glottodydaktyka w ujęciu ekolingwistycznym, „Acta Universitatis Lodziensis. Kształcenie polonistyczne cudzoziemców” 21, s. 51-62.

Zarzycka G., 2019, Kulturemy polskie-punkty widzenia, techniki ich wydobywania i negocjowania. Stosowanie perspektywy etnolingwistycznej w glottodydaktyce polonistycznej, „Acta Universitatis Lodziensis. Kształcenie polonistyczne cudzoziemców” 26, s. 425-442. 


\title{
Iwona Patucka-Czerniak
}

\section{NEEDS, POSSIBILITIES AND CONTEXTS OF INTRODUCTION OF CONTENT RELATED TO HUMAN RIGHTS TO THE TEACHING OF POLISH AS A FOREIGN LANGUAGE}

Keywords: teaching Polish as a foreign language, human rights, intercultural dialogue

\begin{abstract}
The article discusses the introduction of subjects related to human rights to the language training cycle of foreigners studying Polish as a foreign language. The presented reflections are based on the results of projects implemented at the University of Zielona Gora in the period of 2017-2020. The recipients of these activities are mainly adult foreigners who, with great enthusiasm and mutual benefit, accept the extension of teaching content to include human rights issues. Talking on these topics is always associated with revealing the ideology and social philosophy adopted by the listeners (consciously or not). It activates listeners and allows for seamlessly transition from teaching vocabulary and grammar structures to relatively natural communication. It seems beneficial to expand the thematic vocabulary and communication roles by those forms that would teach the communication behaviours needed by foreigners in various situations in which their rights may be violated. The introduction of elements of human rights knowledge to teaching Polish language can create a broad and functional basis for intercultural dialogue, which has a great impact on learning motivation, shapes attitudes of activity and openness, and enriches interaction.
\end{abstract}

